\title{
Vivir en pandemia: un tiempo falso al que solo los números dan verdad
}

\author{
Berenice Romero \\ Pontificia Universidad Católica de Chile
}

\begin{abstract}
A la memoria de Gustavo Puga Morales, ${ }^{1}$ estudiante, cientifico y brillante.
$Y$ en su nombre, al resto de seres a quienes un virus no nos permitió decirles adiós.
\end{abstract}

7353. Siete mil trescientos cincuenta y tres kilómetros es la distancia entre México y Chile. 7353 kilómetros es el número que hace una grieta entre los proyectos no finalizados. SIETE MIL TRESCIENTOS CINCUENTA Y TRES KILOMETROS es la distancia que me impidió decirle adiós a un amigo y quizá tomarle la mano.

Casi a mitad del año que corre, nos enteramos con mayor certeza que a inicios de diciembre del 2019, se identificaron los primeros casos de neumonía de un agente causal presuntamente desconocido, en Wuhan, China. La Organización Mundial de la Salud (OMS) bautizó a este virus como el nuevo Coronavirus 2019 (2019-nCoV). Para el 12 de enero de 2020 el Comité Internacional de Taxonomía de Virus (ICTV) lo nombró como SARS-CoV-2 (Síndrome respiratorio agudo severo Coronavirus 2). El 11 de febrero de 2020 la infección de SARS-CoV-2 fue llamada por la OMS: enfermedad por Coronavirus 2019 (COVID-19, por sus siglas en inglés).

Por si el encierro, el duelo, la incertidumbre y la ansiedad no fueran elementos suficientes para dimensionar la gravedad del asunto y querer subirle los decibeles a la voz, los múltiples papers médicos que circulan en Internet solo presentan escenarios tétricos, aquí un par de datos: de 136 pacientes que presenten paro cardio-respiratorio por COVID-19 solo 18 lograrán salir del paro cardíaco, durante los primeros 30 días solo 4 sobrevivirán y de estos solo 1 alcanzará la mejoría neurológica completa.

Del informe diario de salud de Estados Unidos solo me quedo con esta cifra: 1 de cada 3 pacientes que mueren en EUA por COVID-19 son latinoamericanos.

1 Gustavo Puga Morales era estudiante del último año de doctorado en Ciencias de la Ingeniería en la Pontificia Universidad Católica de Chile. Perdió la vida por COVID-19 un 23 de septiembre de 2020, lo acompañaron sus padres y la leal y fuerte mano de su amiga Natalia. 
Sin embargo, el director de Salud de dicho país, Jerome Adams, señala: «El coronavirus no discrimina. No entiende de razas, de lo que sí entiende, sin embargo, es de condiciones médicas crónicas. Las condiciones más severas las vemos en gente pobre, negros y mestizos, que generalmente tienen una tasa desproporcionada de ellas, debido a los sistemas de salud en este país».

El presidente de Brasil intenta salvaguardar lo más que puede el que para él es el bien más preciado de los últimos tiempos: la economía, por sobre la vida de quien sea. Las proyecciones, de distintos analistas en economía, señalan que entre 5 y 10 millones de personas en Latinoamérica quedarán en absoluta pobreza.

Entre 30 a 40 ocasiones me lavo las manos por día. Restriego agua y jabón en las manos durante 20 segundos. Aprendí que esos mismos segundos son el equivalente a repetir — a veces en voz alta, a veces para mis adentros—: «Vine a Comala porque me dijeron que acá vivía mi padre, un tal Pedro Páramo. Mi madre me lo dijo. Y yo le prometí que vendría a verlo en cuanto ella muriera. Le apreté sus manos en señal de que lo haría; pues ella estaba por morirse y yo en plan de prometerlo todo».

Soy un solo ser y me divido en dos.

El Ministro de Salud de Chile reporta el día de hoy: 504.525 contagios confirmados, 9.035 casos activos, 481.379 recuperados, 14.026 fallecidos. 922 nuevos casos, 549 con síntomas, 300 asintomáticos, 53 sin notificar, 23 muertes atribuibles a COVID-19. La infografía con más números sigue y sigue. Nunca los números fueron tan poco claros.

Soy una cosa viva compuesta de ficción, pero en esta ocasión no.

Dice el Subsecretario de Salud de México, Hugo López Gatell: «Hoy es viernes 23 de octubre de 2020, son las 19:02 horas, estamos en el Palacio Nacional de México en la Ciudad de México y vamos a iniciar la conferencia de prensa diaria sobre COVID-19, la pandemia causada por el coronavirus SARS-CoV-2. Conferencia número 236 desde que se detectó el primer caso en México de SARS-CoV-2».

Un año tiene 365 días. 366 cuando es bisiesto, ese extraño día que sucede una vez cada cuatro años.

Número de habitantes en México: 136.954.835. Número de habitantes en Chile: 18. 729.160. Número de muertos en Chile: 14.026. Número de muertos en México: 89.814. Número de seres amados muertos en México: 0. Número de seres amados muertos en Chile: 1. Los números no cuadran. Las probabilidades fallan. 
Tengo 3647 libros. He leído 2800. He olvidado casi todas las páginas, solo me aferro a uno. No, la literatura no salva. El amor tampoco. La existencia de una vacuna y un mejor sistema de salud, sí, eso sí.

A veces también me parto en cuatro. Barcelona otra vez en confinamiento. Japón eleva la curva.

Los globos aerostáticos elevándose y conquistando el cielo desde 1882 son el escenario que Julian Barnes ocupa como pretexto para narrar las aflicciones y la muerte. En una suerte de alquimia nos habla de las posibilidades de cambiar el mundo al juntar dos cosas y así alterar la suma total de las partes iniciales: «Juntas a dos personas que nunca habían estado juntas. A veces es como aquel primer intento de acoplar un globo de hidrógeno a otro de aire caliente: ¿prefieres estrellarte y arder o arder y estrellarte? Pero a veces funciona y se crea algo nuevo y el mundo cambia. Después, tarde o temprano, en algún momento, por una razón u otra, una de las dos desaparece. Y lo que desaparece es mayor que la suma de lo que había. Esto es quizá matemáticamente imposible, pero es emocionalmente posible». Los números a veces pierden, la literatura acompaña.

A partir de 1994, México se llenó de hermosos discursos que eran entregados por distintos miembros del EZLN. Recuerdo vagamente un pronunciamiento que hacía algún zapatista encapuchado en una entrevista con Luis Villoro: «Sólo cuando nos atrevamos a mirar de frente aquello que más nos duele y aquello que más nos avergüenza de nosotros mismos, seremos capaces de recuperar eso que perdimos hace 500 años y tanta falta nos hace como país: la integridad». Me retumba en especial esa frase del inicio «Sólo cuando nos atrevamos a mirar de frente aquello que más nos duele...», hace meses que no miro nada de frente, más bien me quedo mirando hacia arriba, hacia el techo blanco, mientras cuento no sé qué cosas en el cielo raso y espero a ponerme en blanco.

Las olas con su espuma blanca regresando al mar es la concepción de la muerte para los budistas. La forma con la que lo explican es la siguiente: imagina una ola en el océano, ves su altura, la mides, miras como el sol parece atravesarla con una luz refractada. Esa misma ola se rompe cuando llega a la orilla del mar, la ola desaparece, ya no está, pero el agua sigue ahí. La ola fue otra forma del agua por un tiempo. La ola regresa al lugar de donde vino y donde debería estar, al mar.

Se habla de un posible rebrote en México. 19 entidades federativas de las 32 regresan del semáforo amarillo al naranja. 1 pasa del naranja al rojo. Solo 1 estado está en verde. El resto, por el momento, continúa en amarillo. ¿A dónde debemos regresar los humanos? Porque es un hecho que no es al mar. 
Vivir en pandemia: un tiempo falso al que solo los números dan verdad

Berenice Romero

El resultado de votación por un cambio de Constitución en Chile es del 82,25 por ciento. El deseo por una nueva Constitución se revela con contundencia: 8 de cada 10 votantes fueron por el Apruebo. Aún está abierta la invitación para unirnos al baile de los que sobran. Después de todo aún hay vida. O eso indican los números.

En la primavera chilena, 2020. En el otoño mexicano, 2020. 